\title{
Female Directors and Firm Performance: Evidence from UK Listed Firms ${ }^{0}$
}

\author{
Pananda Pasaribu \\ Kwik Kian Gie School of Business, Jakarta, Indonesia
}

\begin{abstract}
The impact of female directors on firm performance has lacked consistency in the previously conducted empirical studies, which may be due to the endogeneity problem, or certain characteristics (i.e. governance, industry, competition). This study examines the relationship between female directors and firm performance by addressing those problems. This study analyses all non-financial UK listed firms during the period 2004-2012 and employs several econometric models. The regression results indicate that there is little evidence that female directors have a positive and strong relationship with firm performance. But, further analysis reports that the UK's small listed firms experience a positive significant effect, because small firms do not suffer from the problem of over-monitoring and they have more flexibility in composing their boards of directors.
\end{abstract}

Keywords: board diversity; female director; size effect

JEL classification: G30, G34, J16

${ }^{0}$ The manuscript is part of the author's Ph.D. Dissertation

* Corresponding author's e-mail: pananda@kwikkiangie.ac.id 


\section{Introduction}

Gender diversity on the boards of directors has been of major interest to corporate governance in recent years. Because of the apparent under-representation of females on the boards of directors, some EU countries (i.e. Norway, Finland) have introduced the idea of imposing quotas for female directors on the boards of large corporations (Smith et al. 2006; Nekhili and Gatfaoui 2013; Chapple and Humprey 2014).

In the UK, although there has been no formal regulation or law, the Davies report explicitly recommends a 25 percent representation by females on the boards of FTSE100 firms by 2015. As a consequence, the latest figures indicate that female directorships in FTSE index firms have increased from 12 percent in 2011 to 25 percent in 2014 (Stern 2014). In other words, the government intervention successfully allowed female candidates to gain better access to the UK listed firms' boardrooms.

Nevertheless, knowledge of the impact of female directors on firm performance lacks consistency. Some studies (Erhardt et al. 2003; Carter et al. 2003; Campbell and Minguez-Vera. 2007; Luckerath-Rovers 2013; Liu et al. 2014; Strom et al. 2014, Green and Homroy 2016) report positive impacts, while others (Smith et al. 2006; Adams and Ferreira. 2009; Carter et al. 2010; Galbreath 2011; Jurkus et al. 2011; Ahern and Dittmar 2012) fail to report the same result.

The purpose of this study is to examine the relationship between female directors and firm performance. This study contributes to the governance studies, which specifically discuss female directors, via three channels. Firstly, this study uses rigorous econometric techniques in order to address the endogeneity problems (Adams and Ferreira 2009;
Liu et al. 2014; Strom et al. 2014). Secondly, this study uses a larger dataset than previous related studies in the UK (Ryan and Haslam 2005; Gregory-Smith et al. 2013). Finally, this study adds analysis of the firms' sizes, as the UK's large listed firms encounter a certain kind of pressure in the composition of their boards' members (Mallin and Ow-Yong 2008).

The analysis reveals that female directors tend not to significantly influence firm performance. At first, the estimations of female directors tended to have positive and significant estimations in the OLS model, but the sign and significance change in the two stage-least-square and GMM models, which suggests female directors and firm performance suffer from an endogeneity problem. Moreover, by splitting the sample, there is strong evidence that firm size may affect the relationship between female directors and firm performance. Small firms tend to gain the most benefits from appointing female directors, because these firms suffer less from outside intervention than the large firms, in terms of composing their boards' structures.

The remainder of the study is organized as follows: Section 2 discusses the theoretical perspective of board (gender) diversity. Section 3 and Section 4 look at the hypotheses development and research methodology respectively. Section 5 provides the empirical evidence of the study. Finally, Section 6 is the conclusion of the study.

\section{Literature Review}

Robinson and Dechant (1997) argue that board diversity can enhance the growth of a firm's business through several ways. (1) As the market becomes more diverse in terms of race and ethnicity, aligning the board's diversity with a market demographic enhances 
the understanding of the current and potential market. (2) Board diversity improves creativity and innovation because different races, ages, and genders are associated with different attitudes, cognitives, and beliefs. (3) Board diversity improves the decision making processes that lead to better problem solving. (4) Board diversity enhances effective leadership. (5) Board diversity promotes global relationships and strategic advantages in global competition.

From the agency theory's point of view, there are several ways to link gender diversity on the boards and agency problems. Firstly, Carter et al. (2003) argues that board diversity is equivalent to board independence, because diverse boards do not have the traditional backgrounds that insider directors have. Thus, more diverse boards will reduce agency problems. Secondly, Ahern and Dittmar (2012) argue that appointing female directors can reduce the influence of a CEO, who may be pursuing his/her own private agenda, rather than working for the shareholders' interests (Bebchuk and Fried 2005). Appointing female directors can also reduce the agency cost.

Hillman et al. (2000), supporting the resource based theory, argues that diverse boards provide more unique resources and information, that may benefit the decision making processes. Within a diverse board, there exist diverse perspectives and non-traditional alternatives to certain problems. Hillman et al. (2007) argues that a board's diversity shows the firm's commitment to minorities, which can add legitimacy to a firm. It gives a signal that firms do promote equal opportunities for current and potential employees.

The stakeholder theory's view is that the board's main duty is to maintain good relationships with the stakeholders (customers, regulators, creditors, etc.). The proponents of the stakeholder theory argue that corporations should reflect their external environment, for instance their society, which is composed of different genders, races, and ethnic groups. As a result, gender diversity on the board is a rational consequence, or even an obligatory implication, for some countries. However, Rose (2007) argues that imposing such a law may not be appropriate for listed firms, as they are different from democratic institutions.

The human capital theory is related to the directors' characteristics which are useful and beneficial to firms. Singh et al. (2008) reports that female directors in FTSE100 companies tend to have an MBA degree and international experience. Sealy et al. (2007) reports that female directors tend to have a title with their name, for instance an academic title (Prof, Dr), civic or political titles (Dame, Baroness), or aristocratic titles (Lady, Honourable). Terjesen et al. (2009) reports that female qualifications are relatively similar to male qualifications, but females tend to be less experienced than males in terms of their business experience. Similarly, Singh and Vinnicombe (2004) argue that the lack of female networks and experience in executive positions are the main reason why females are less attractive than their male counterparts.

Given those theories, there are two important inferences. Firstly, the presence of females on the board is not entirely based on reasons connected to the businesses' perspective. There is substantial pressure from the firms' external environment (e.g. female directors' quotas) which influences the decision to hire female directors (Singh and Vinnicombe 2004). Secondly, as a consequence of the first implication, the effects of gender diversity on the board may not be optimal for the board, in terms of its effec- 
tiveness and firm performance. Terjesen et al. (2009) argues that female directors can improve a board's effectiveness and firm performance in many ways, but they may not directly influence a firm's bottom line, due to multi-level processes.

\section{Hypothesis Development}

There are two objectives in the study: (1) examining the effect of gender diversity on the boards and (2) examining the effect of gender diversity on firm performance, with respect to firm size. This section tries to develop the hypotheses for each of the study's objectives.

\section{Gender Diversity and Firm Performance}

Gender inequality on the boards of directors has been a systemic problem in the corporate world. Consequently, governments, particularly in the developed countries, have imposed quotas to increase the presence of females on the boards. They argue that increasing the diversity of the boards brings a larger pool of talent, in terms of their expertise, experience, and connections, which leads to better governance and firm performance (The Davies report 2012). This means that there is a positive relationship between female directors and firm performance

However, prior empirical studies have been inconsistent in their reporting of the contribution of female directors to firm performance. Several studies have found a positive association between gender diversity and firm performance (Carter et al. 2003; Erhardt et al. 2003; Carter et al. 2003; Campbell and Minguez-Vera 2007; Luckerath-Rovers 2013).

There are two reasons why these studies successfully report a positive association.
Firstly, all of the empirical analyses in those studies are not that advanced, which makes it difficult to decide whether the result is correct, or implies an endogeneity issue. Secondly, most of them were conducted in the early 2000s, when the quota rules on gender diversity had not yet been introduced. Firms in the 1990s and the early 2000s had more flexibility in composing their boards than those in the middle or late 2000 s do.

While most of those studies focused on firms in developed countries, Liu et al. (2014) investigated gender diversity in Chinese listed firms and Strom et al. (2014) used firms from 73 developing countries. Both studies report that female directors significantly affect firm performance in the developing markets, in which listed firms are less regulated.

By contrast, other studies do not find evidence that females directly influence firm performance. Adams and Ferreira (2009) report a negative association between female directors and firm performance in the US. A positive association cannot be found in the Scandinavian countries, in which gender diversity has been mandated by law (Smith et al. 2006; Rose 2007 Ahern and Dittmar 2012).

Consistently, the UK-based studies tend to indicate that there is no positive association between gender diversity on the boards and firm performance. Haslam et al. (2010) reports that there is no association between the presence of female directors on a board and firm performance for FTSE100 companies. Gregory-Smith et al. (2013) did not find evidence that the presence of females on boards is associated with higher firm performance.

Ideally, firms are free to appoint directors without considering their directors' gender. But, the UK market regulator, through the Davies report, has explicitly recommended 
boards comprising of 25 percent female directors. It means that firms appoint female directors because of pressure being applied, rather than for strategic reasons or the qualifications of the candidates. This kind of pressure does improve firm performance (Ahern and Dittmar 2012; Low et al. 2015). Therefore, the null hypothesis is:

$$
\begin{aligned}
H_{1}: & \text { Gender diversity on the boards has no impact } \\
& \text { on firm performance in the UK. }
\end{aligned}
$$

\section{Firm Size Effect}

The size of firm has been scrutinized in finance studies such as in the models of asset pricing (Fama and French 1993), the decisions of financing or capital structure (Berger and Udell 1995), the decisions of merger and acquisition (Moeller et al. 2004; Offenberg 2009), and the effectiveness of the board of directors (Setia-Atmaja 2008). In other words, the size of firms have important role in many aspects of finance studies.

In the UK, the market regulator imposes different standards in terms of disclosure and governance practices, according to the size of a firm. For instance, firms that are listed on the Alternative Investment Market (AIM) are not obliged to follow all the The UK Corporate Governance Code (Mallin and OwYong 2008). In other words, the AIM firms are in a less-regulated environment than the large firms (e.g. FTSE100 and FTSE250). Dahya et al (2002) reported that there is a significant difference between large firms and small firms with regard to their compliance with the Cadbury recommendations. Moreover, the recommendation to appoint more female directors is aimed at the FTSE100 firms (Davies Report 2012).
The recent report indicates that small firms may have different governance practices from the large firms among the Russell 3000 companies. ${ }^{1}$ Small firms tend to have less board committee (audit, compensation, nomination) meetings, staggered boards, less independent directors, and fewer females on their boards. This report supports previous studies, in which larger firms tend to have more non-executive directors (Denis and Sarin 1999) and entrenched CEOs (Hazarika et al. 2012), which leads to their low levels of governance index (Farag et al. 2014).

Appointing female directors is highly associated with a board's effectiveness (Adams and Ferreira 2009; Jurkus et al. 2011; Abbot et al. 2012; Srinidhi et al. 2011; Kyaw et al. 2015; Chen et al. 2016) in terms of: (1) better governance and a good atmosphere in the board room; (2) accountability and transparency in financial reporting; (3) improved decision-making in investment and financing decisions. Appointing female directors to firms with strong governance, which is proxied by the large firms, leads to the problem of over-monitoring. Therefore, the null hypotheses with respect to firm size are:

$H_{2}$ : Gender diversity on the boards has no impact for large listed firms in the UK

$H_{3}$ : Gender diversity on the boards has no impact for small listed firms in the UK

\section{Research Framework}

This study tries to investigate the relationship between female directors and firm performance by examining without (Figure 1.a) and with (Figure 1.b) the effect of firm size. As the composition of the boards of large firms tends to suffer from government

${ }^{1}$ Ernst and Young Corporate Governance Centre. May 2013. Governance Trends and Practices at US Companies: A Review of Small and Mid-sized Companies. 
Figure 1. Research Framework

(A)

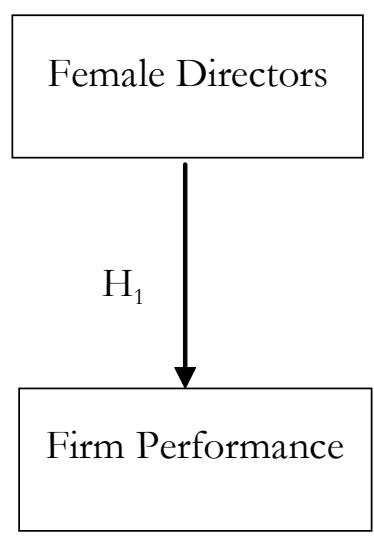

(B)

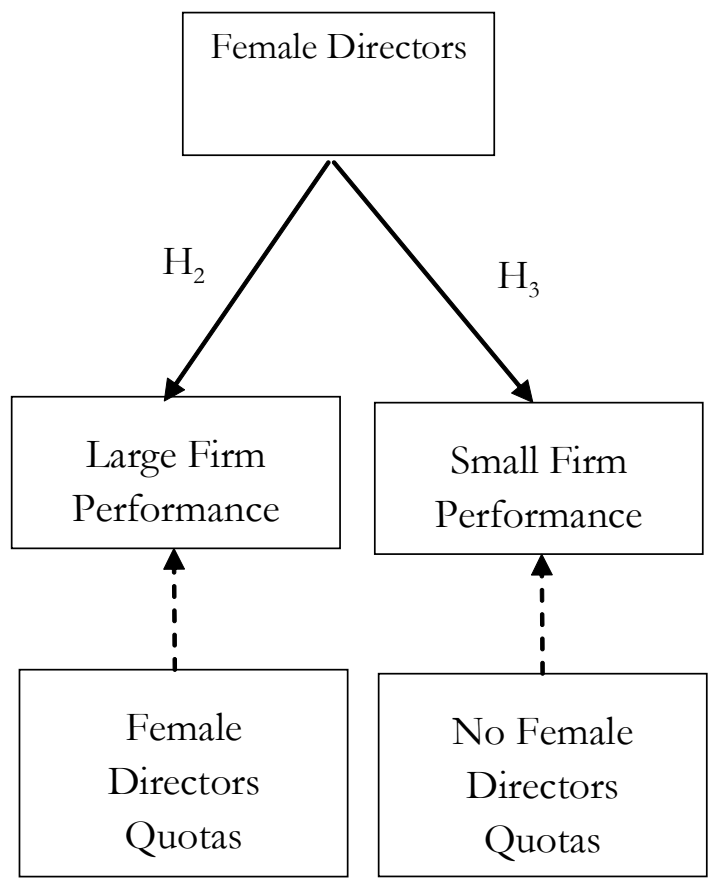

(1) the firms must be non-financial firms, those that have an Industry Classification Benchmark (ICB) equal to 8 are excluded from the sample; (2) due to the lack of available data on boards of directors, the headquarters of the selected firms must be in the UK.

This study uses multiple sources to obtain the variables under investigation. The data on firms' board characteristics were mostly obtained from the Financial Analysis Made Easy (FAME) database, such as thename, date of birth, nationality, gender, date of appointment, of directors. The positions (e.g. CEO, chairman, financial director) and functions (e.g. executive and non-executive) are obtained from the Thomson ONE Banker and the Bloomberg databases, which were hand-collected. Proxies for firms' performance came from the FAME and the Bloomberg databases. 


\section{Regression Model and Variables}

The general form of the regression model is as Equation 1.

$$
\begin{aligned}
& \text { Firm } \quad \alpha+\beta \text { Female_Directors_Measure }_{\text {it }} \\
& \text { Perfomance }_{\text {it }}=+\lambda \text { Board_Characteristics }_{\text {it }} \\
& +\gamma \text { Firm_Characteristics }_{\text {it }}+\zeta \\
& +\theta_{\mathrm{t}}+\mathrm{e}_{\mathrm{it}}
\end{aligned}
$$

Where $i$ indexes the firms and $t$ is a yearly time index. The $\zeta_{k}$ and $\theta_{t}$ variables represent the firms' industry and year respectively. The female directors' measure is the fraction of female directors on the boards, while the boards' characteristics, and firms' character- istics contain several variables which can be seen in Table 1.

There were three regression models used in this study, which were the OLS model, the two-Staged Least Square (2SLS) model and the Arellano-Bond model. Previous studies (Adams and Ferreira 2009; Liu et al. 2014) indicate that the OLS model is prone to causal problems, in which positive estimations mean well-performing firms tend to appoint female directors rather than the presence of female directors increasing firm per-

\begin{tabular}{|c|c|}
\hline Variables & Descriptions \\
\hline \multicolumn{2}{|c|}{ Dependent Variables } \\
\hline ROA & $\begin{array}{l}\text { Ratio between net-income and book value of total assets at the end of } \\
\text { year }\end{array}$ \\
\hline Profit margin & Net profit divided by total turnover (sales) \\
\hline \multicolumn{2}{|l|}{ Gender Diversity } \\
\hline Fract_female & Ratio between female directors and total directors \\
\hline \multicolumn{2}{|c|}{ Board Characteristics } \\
\hline Board size & Total number of directors \\
\hline Fract_ned & The number of non-executive director divided by board size \\
\hline \multicolumn{2}{|c|}{ Firm Characteristics } \\
\hline Firm size & Logarithm of total asset \\
\hline Firm age & The difference between year-t with firm establishment year \\
\hline Blockholder & The percentage of firm ownership that held by the largest shareholder \\
\hline Debt ratio & Total debt divided by total assets \\
\hline Total employee & Logarithm of firm total employee \\
\hline \multicolumn{2}{|c|}{ Instrumental Variables } \\
\hline Fem_exp & $\begin{array}{l}\text { The fraction of man director to total directors who have connection to } \\
\text { female director }\end{array}$ \\
\hline ICB_one & Fraction of female in the same one-digit ICB code industry \\
\hline ICB_two & Fraction of female in the same two-digit ICB code industry \\
\hline ICB_three & Fraction of female in the same three-digit ICB code industry \\
\hline ICB_four & Fraction of female in the same four-digit ICB code industry \\
\hline
\end{tabular}
formance. This term is known as the endogeneity problem.

\section{Table 1. Variable Descriptions}


Wooldridge (2010) recommends a twostep procedure to address this endogeneity. The first step is to regress the suspected endogenous variable, which is the female directors, with all the possible predetermined variables. The second step is to use the predicted values of the endogenous variable from the $1^{\text {st }}$ regression as an explanatory variable in the model of interest.

In order to employ the 2SLS models, it is necessary to find the instrumental variables. This study used two instrumental variables to address them. The variables are the male directors' connection to the female directors (Adams and Ferreira 2009; Levi et al. 2013) and the fraction of female directors in the same industry (Brammer et al. 2007; Liu et al. 2014). It is expected that both variables are positive.

The Instrumental Variable model ( $1^{\text {st }}$ stage regression) is:

$$
\begin{array}{ll}
\text { Female } & \begin{array}{l}
\alpha+\delta 1 \text { Male_connection }_{\text {it }} \\
\text { Directors }_{\text {it }}= \\
+\delta 2 \text { Demale_industry }_{\text {it }} \\
+\gamma \text { Firm_Characteristics }_{\text {it }}
\end{array} \\
& \mathrm{e}_{\mathrm{it}} \ldots \theta_{\mathrm{t}}+
\end{array}
$$

The final model is the Arellano-Bond model. This model is known as a dynamic model because the model includes the lagged firm performance as an explanatory variable. Thus Equation 2 is transformed into:

$$
\begin{aligned}
& \text { Female Firm Perfomance }{ }_{i t-1} \\
& \begin{aligned}
\text { Directors }_{\text {it }}= & \begin{array}{l}
+ \text { Female_Directors_Measure } \\
\\
\end{array} \text {, Board_Characteristics. }
\end{aligned} \\
& + \text { Firm_Characteristics } \\
& +\theta_{\mathrm{t}}+\mathrm{e}_{\mathrm{it}}
\end{aligned}
$$

The specification of the Arellano-Bond model is very important when addressing the endogeneity issue. This study employs the same approach as Adams and Ferreira (2009), who used two lagged periods and all the subsequent lagged periods of firm performance, and the one period lag of the independent variables as the instrumental variables.

This study used two dependent variables, which are the Return On Assets (ROA) and the profit margin. Both measures have been widely used in previous female director related studies, for instance ROA is in Erhardt et al. (2003), Adams and Ferreira (2009), and Strom et al. (2014) while the profit margin has been used by Smith et al. (2006) and Liu et al. (2014). The full definitions of the dependent and independent variables can be seen in Table1.

\section{Results}

This section is divided into four sections, which are the descriptive analysis, instrumental variable analysis, regression analysis, and research discussion.

\section{Descriptive Analysis}

Table 2 indicates the development of female directors in the UK's non-financial listed firms. There is a tendency that more listed firms are hiring female directors. In 2004, 73.8 percent of the total number of firms did not have a female on their board, but that figure has reduced to 59 percent by 2012. The fraction of female directors who sit on the boards has increased gradually, from 5.0 percent to 8.8 percent during the period 2004 to 2012.

Even though more female directors have been appointed, the proportion of females who are hired as executive directors has tended to be stagnant. The fraction of nonexecutive female directors has increased by more than twice between 2004 and 2012, while the fraction of executive directors remains at around 2.5 percent. 
Table 2. The Development of Female Director in the UK listed Firms between 2004 and 2012

\begin{tabular}{lcccccccc}
\hline Year & Firms & $\begin{array}{c}\text { Number } \\
\text { of } \\
\text { Directors }\end{array}$ & $\begin{array}{c}\text { Fraction } \\
\text { of } \\
\text { Females }\end{array}$ & $\begin{array}{c}\text { Fraction of } \\
\text { NED } \\
\text { Females }\end{array}$ & $\begin{array}{c}\text { Fraction of } \\
\text { Executive } \\
\text { Females }\end{array}$ & $\begin{array}{c}\text { Firms with } \\
\text { no Female } \\
\text { Director }\end{array}$ & $\begin{array}{c}\text { Female } \\
\text { CEO }\end{array}$ & $\begin{array}{c}\text { Female } \\
\text { Chair }\end{array}$ \\
\hline $\mathbf{2 0 0 4}$ & 1,181 & 7,628 & 0.050 & 0.026 & 0.024 & 0.738 & 0.025 & 0.007 \\
$\mathbf{2 0 0 5}$ & 1,366 & 8,787 & 0.056 & 0.030 & 0.026 & 0.717 & 0.031 & 0.007 \\
$\mathbf{2 0 0 6}$ & 1,401 & 8,882 & 0.058 & 0.032 & 0.026 & 0.707 & 0.037 & 0.009 \\
$\mathbf{2 0 0 7}$ & 1,373 & 8,765 & 0.059 & 0.032 & 0.027 & 0.706 & 0.039 & 0.012 \\
$\mathbf{2 0 0 8}$ & 1,241 & 7,922 & 0.060 & 0.034 & 0.026 & 0.695 & 0.038 & 0.013 \\
$\mathbf{2 0 0 9}$ & 1,119 & 7,104 & 0.063 & 0.038 & 0.025 & 0.685 & 0.036 & 0.013 \\
$\mathbf{2 0 1 0}$ & 1,053 & 6,809 & 0.067 & 0.043 & 0.024 & 0.666 & 0.036 & 0.015 \\
$\mathbf{2 0 1 1}$ & 998 & 6,500 & 0.074 & 0.050 & 0.024 & 0.643 & 0.035 & 0.018 \\
$\mathbf{2 0 1 2}$ & 948 & 6,222 & 0.088 & 0.063 & 0.025 & 0.590 & 0.033 & 0.019 \\
\hline
\end{tabular}

Directors are total individuals (directors) in the sample. Fraction of female is total female director divided by total directors. Female NED is total female non-executive director divided by directors. Female exec is total female executive director divided by total director. No female director is the fraction of firms with no female director. One female director is the fraction of firm with one female director. Two female directors is the fraction of firms with two female directors. Three or more female director is the fraction of firms with three or more female director. Female CEO is the fraction of firms with female CEO. Female Chair is the fraction of firm with chairwoman.

Table 3. Descriptive Statistics

\begin{tabular}{lcccccc}
\hline \multicolumn{1}{c}{ Variable } & $\mathbf{N}$ & Mean & StdDev & Q1 & Median & Q3 \\
\hline $\begin{array}{l}\text { CEO characteristics } \\
\text { Outsider_code }\end{array}$ & 10,656 & 0.31 & 0.46 & 0.00 & 0.00 & 1.00 \\
Board Characteristics & & & & & & \\
board_size & 10,680 & 6.43 & 2.28 & 5.00 & 6.00 & 8.00 \\
prop_ned & 10,680 & 0.51 & 0.16 & 0.40 & 0.50 & 0.63 \\
prop_ined & 10,680 & 0.40 & 0.19 & 0.29 & 0.40 & 0.55 \\
Firm Performance & & & & & & \\
roa & 10,217 & -0.08 & 0.37 & -0.10 & 0.03 & 0.09 \\
prof_margin & 9,473 & -2.10 & 10.95 & -0.10 & 0.03 & 0.08 \\
Firm Characteristics & & & & & & \\
asset ('000) & 10,249 & 890,411 & $3,433,844$ & 10,132 & 42,200 & 218,414 \\
employ & 10,049 & 4,533 & 14,035 & 53 & 255 & 1,714 \\
firm_age & 10,680 & 23.19 & 28.23 & 5.58 & 10.98 & 26.23 \\
block & 10,467 & 0.22 & 0.15 & 0.12 & 0.17 & 0.27 \\
debt_ratio & 10,246 & 0.51 & 0.34 & 0.28 & 0.48 & 0.67 \\
Instrumental Variables & & & & & & 0.06 \\
icb_three & 10,656 & 0.07 & 0.03 & 0.04 & 0.06 & 0.09 \\
fem_exp & 10,680 & 0.30 & 0.26 & 0.00 & 0.25 & 0.50 \\
\hline
\end{tabular}

Outsider_code equals to 1 if the CEO is not the owner or CEO joins the firm less than 1 year, owner_code equals to 0 if else. Board_size is total of director. prop_ned is the fraction of non-executive director. prop_ined is the fraction of independent non-executive director. roa is net profit divided by total asset (ROA). prof_margin is net profit divided by total sales (profit margin). Asset is total firm assets. Employf2 is total firm employee. firm_age is the difference between end date of calendar year and firm establishment date. block is percentage owned by top blockholder. Debt_ratio is total debt divided by total asset. ICB_three is the fraction of female director within the same 3-digit industry code. Fem_exp is the fraction of male director who ever works with female director on other board. roa, prof_margin, asset, employe and debt_ratio are winsorized at 1 percent and 99 percent 

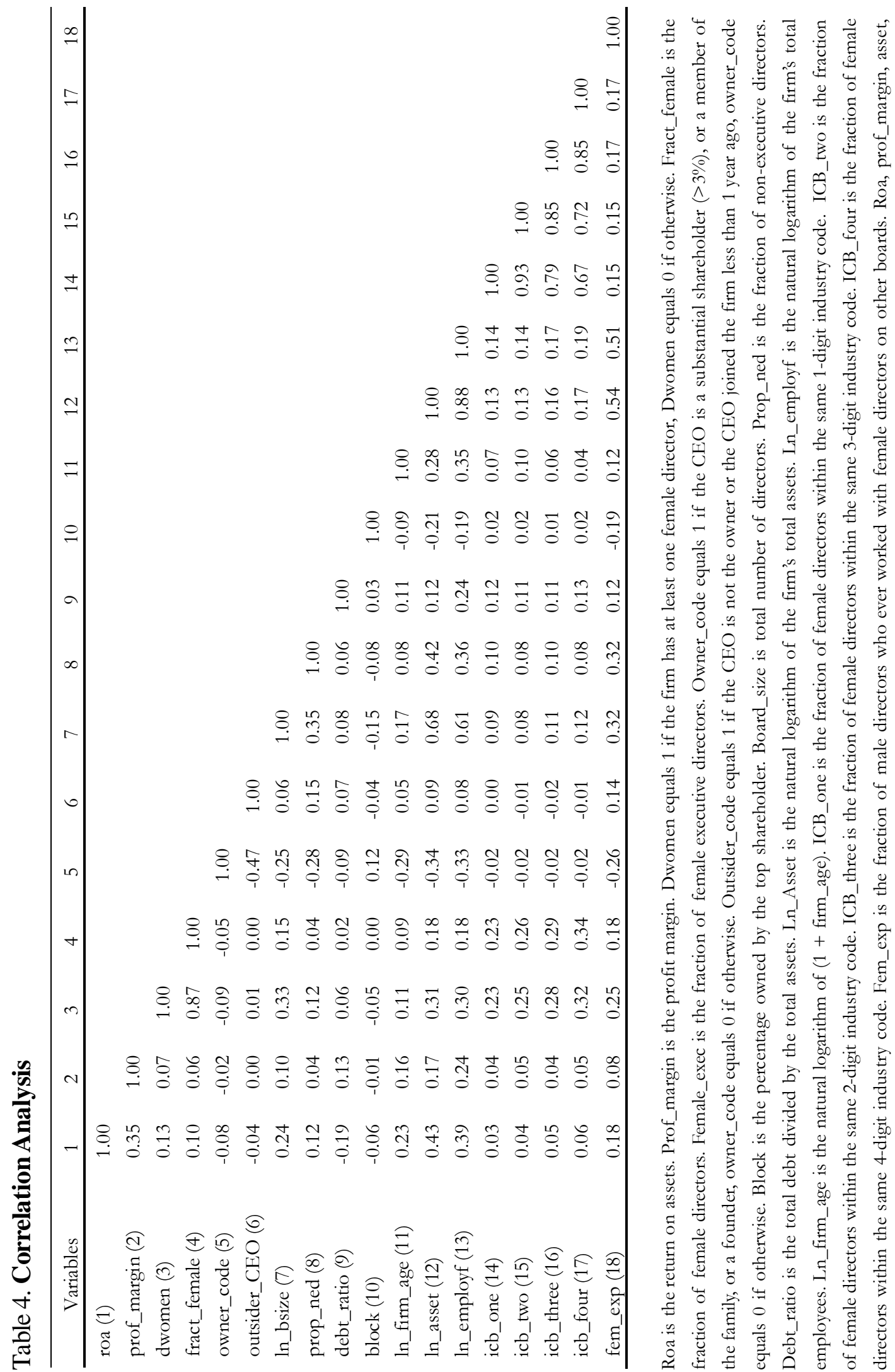

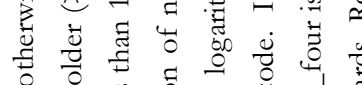

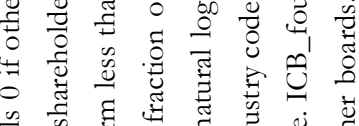

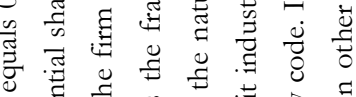

可

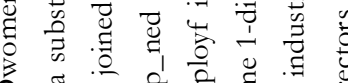

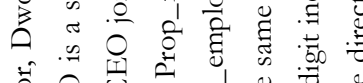

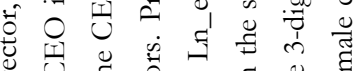

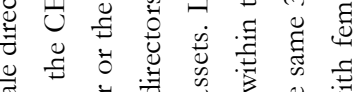

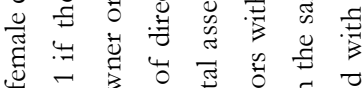

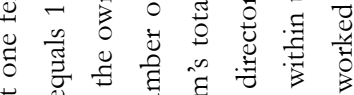
茛

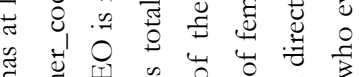

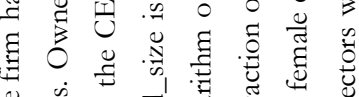
ఫ

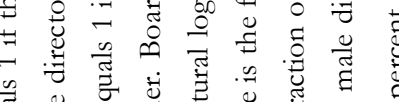

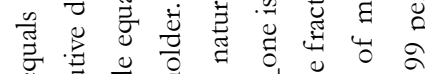

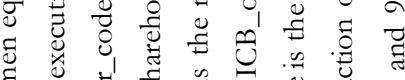

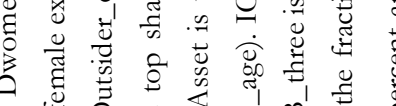

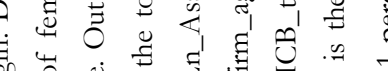

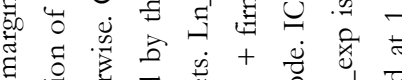

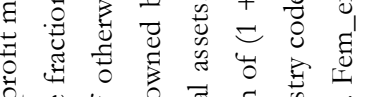

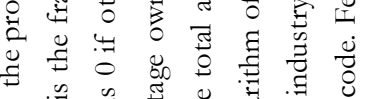

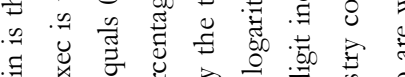

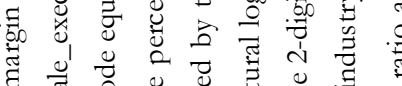

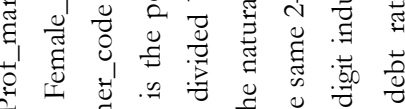

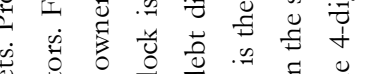

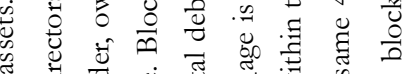

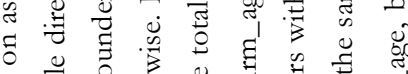

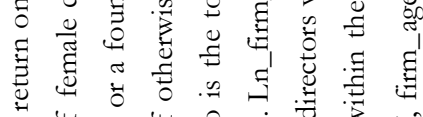

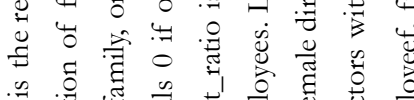

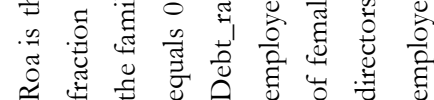


Yet, less than 4 percent of the total number of firms have appointed a female as their CEO. These results are relatively similar to previous studies (Ahern and Dittmar 2012; Gregory-Smith et al. 2013), in which the increase in female participation on boards is more likely to be through the non-executive function rather than any executive function, which could suggest that there still exists gender bias in the appointment of the executive directors.

Table 3 shows the mean, median, standard deviation, and $25^{\text {th }}$ and $75^{\text {th }}$ percentiles of the variables that are possibly used in the regression analyses. There is a significant difference in the available observations in relation to the firms' profit margins. This discrepancy may be as a result of using two databases, which are the FAME database (UKbased) and the Bloomberg database (USbased). In this case, the Bloomberg database may not provide financial information on the firms that are being delisted or acquired by other firms.

The mean of board size for UK listed firms is between 6 and 7 directors, of which about half are non-executive directors. The final section in Table 3 shows the instrumental variables, which are the fraction of females within the same 3 digit-ICB code and the fraction of male directors who work with a female director on other boards. The means of both variables are 7 percent and 28 percent respectively. The detail of these variables is discussed in the next section.

Table 4 show the correlation between firm performance measures, female representative measures and the other controls variables. Multicolinearity is likely to happen when the absolute value of the coefficient correlation is close to 0.7 or higher. This study uses two proxies to measure firm size, which are firms' total assets and firms' total employ- ees. Both variables have a strong positive correlation with board size. Large firms tend to have large boards as well. As a consequence, this study uses the total employees as a proxy of firm size rather than the total assets in the regression analysis.

The instrumental variables also have positive correlations with the fraction of female directors, as previously expected. There is an early sign that firms tend to follow other firms with the same ICB code, in terms of the level of female participation on their boards. Likewise, the fraction of male directors who work with female directors on other boards has a positive correlation with the number of female directors. Those relationships are substantially higher for firms with non-executive female directors than for firms with female executive directors.

Table 5 compares the firm characteristics between firms that have at least one female director and firms with no female directors, across firm-years. Most of the characteristics of a firm that hires at least one female director are different from those of firms with no female directors. Firms with female directors tend to be bigger (in terms of their total number of employees and board's size), more profitable, more efficient, and be well established than the firms with no female directors. Table 5 indicates that firms with female directors tend to be more profitable than firms with no female directors.

\section{Instrumental Variable Analysis}

Figure 1 shows the distribution of female directors for UK listed firms according to the 2-digit ICB code. Firms are likely to hire female directors when they are consumer based, such as in the retail, media, personal and household goods, and healthcare sectors. 
Table 5. Comparisons between Firm with and without Female Director

\begin{tabular}{lrrrrr}
\hline \multirow{2}{*}{$\begin{array}{c}\text { Firms } \\
\text { Characteristics }\end{array}$} & \multicolumn{2}{c}{$\begin{array}{c}\text { Firms with Female } \\
\text { Director }\end{array}$} & \multicolumn{2}{c}{$\begin{array}{c}\text { Firms without } \\
\text { Female Director }\end{array}$} & Difference \\
\cline { 2 - 5 } & \multicolumn{1}{c}{$\mathbf{N}$} & Mean & \multicolumn{1}{c}{$\mathbf{N}$} & Mean & \\
\hline ROA & 3,233 & -0.01 & 6,984 & -0.11 & $0.10^{* * *}$ \\
Profit Margin & 3,093 & -1.01 & 6,380 & -2.63 & $1.62^{* * *}$ \\
Board Size & 3,337 & 7.59 & 7,343 & 5.89 & $1.70^{* * *}$ \\
Fraction of NED & 3,337 & 0.54 & 7,343 & 0.49 & $0.05^{* * *}$ \\
Total Employee & 3,199 & $12,501.50$ & 6,850 & $2,361.40$ & $10,140.10^{* * *}$ \\
Blockholder & 3,280 & 0.20 & 7,187 & 0.22 & $0.02^{* * *}$ \\
Firm Age & 3,337 & 26.85 & 7,343 & 21.54 & $5.31^{* * *}$ \\
Debt Ratio & 3,236 & 0.56 & 7,010 & 0.81 & $0.25^{* * *}$ \\
\hline
\end{tabular}

ROA is net profit divided by total asset. profit margin is net profit divided by total sales. Board size is total of director. Fraction of NED is the fraction of non-executive director. Total employee is total firm employee. Blockholder is percentage owned by top blockholder. Firm age is the difference between end date of calendar year and firm establishment date. Debt ratio is total debt divided by total asset. *** indicates significance at the 1 percent level

Figure 1. Mean of Fraction of Female Directors Based on the Industry

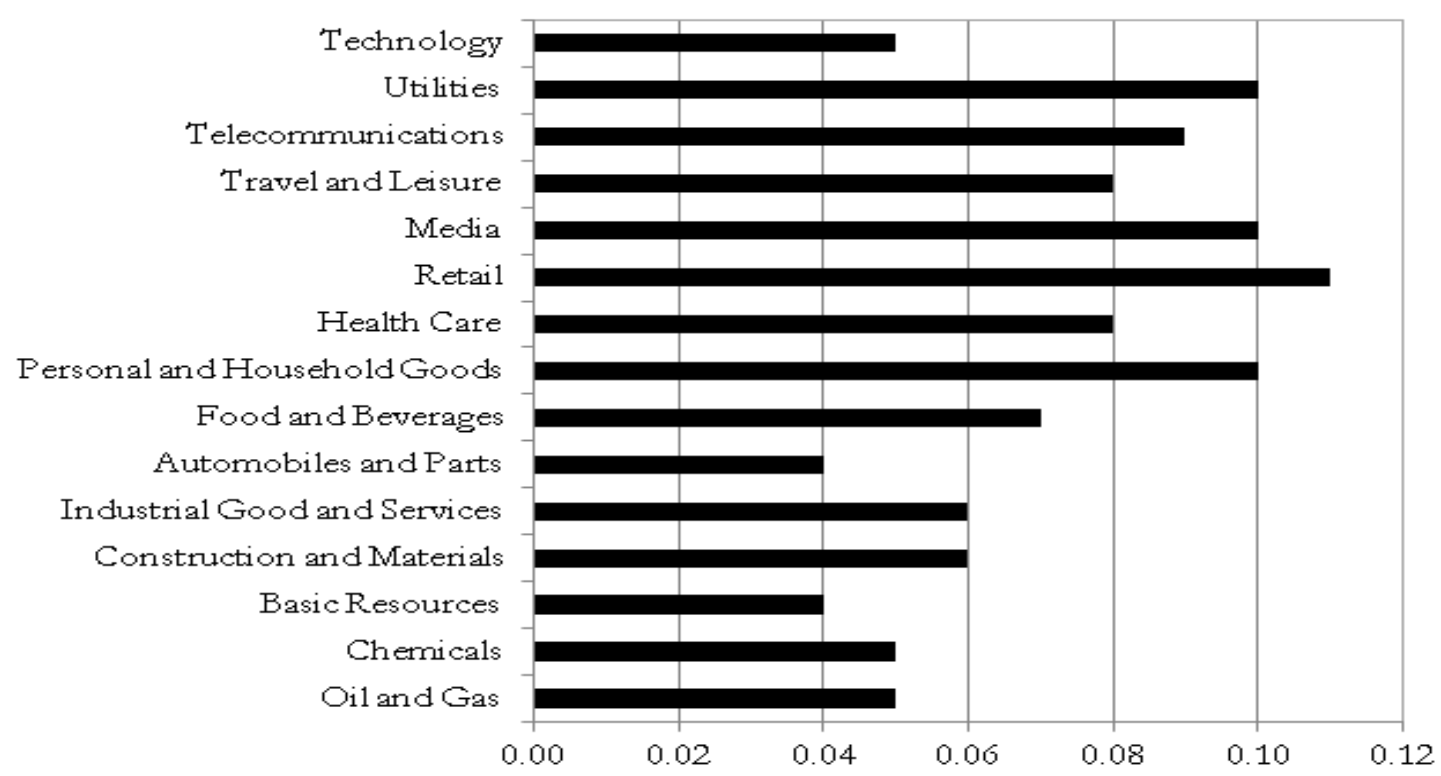

The participation of females on boards is also relatively high in the utilities and telecommunications sectors. Conversely, the number of female directors is low for firms in automobiles and parts, chemicals, basic resources, and the oil and gas sectors. This instrumental variable is expected to have a positive association with the fraction of female directors in the regression analysis. 


\section{The Regression Analysis}

This section is divided into two sections, which are the analysis of all the observations and the analysis of the small and large firms.

\section{Analysis of female directors on firm performance}

Table 6 presents the regression estimations between the ROA (dependent variable) and the independent variables for all the observations. ${ }^{2}$ The fraction of female directors in the OLS regression analysis is positively associated with firms' ROA, which is relatively the same as found by previous studies (Adams and Ferreira 2009; Liu et al. 2014). However, the results are prone to endogeneity problems

In Model 2 and Model 3, this study employs a two-stage least regression. Model 2 and Model 3 usethe fraction of males with connections to female directors (fem_exp) and the fraction of female directors in the same industry (icb_code) as the instrumental variables. There are several ways to check the reliability and effectiveness of the instrumental variables in the STATA software. Firstly, it can be done by checking the significance of the instrumental variables in the first stage regression. When the instrumental variables are statistically significant, the fraction of female directors is successfully instrumented. Secondly, by checking the F-test in the first stage regression; when the F-test is lower than 10 , then the models experience a weak instrumental variables problem. Thirdly, by checking the p-value of the Sargan statistics in the second stage regression. Fourthly, this study conducted an endogeneity test for the suspected endogenous variable in the second stage regression. For the last two approaches, when the $\mathrm{P}$-value is higher than the 10 percent level, it can be inferred that the instrumental variables work properly and the problem can be fully addressed.

The results of first stage regression (Model 2 and Model 3) in Table 6 indicate that the instrumental variables are highly correlated with the endogenous variable (the fraction of female directors). The signs of both Instrumental Variables (IVs) are positive, which means that the more male directors there are who have connections with female directors then the more likely it is that firms will hire female directors. Moreover, it is likely that firms follow the composition of male and female directors in other firms within the same industry code.

Both Model 2 and Model 3 use the same instrumental variables, which are the fraction of male directors who work with female directors (fem_exp) and the 2-digit industry code (icb_two). Generally, the more specific the industry classification is, the larger the Ftest value is in the first stage regression, which may also be associated with the higher P-values in the Sargan and endogeneity tests in the second stage regression. Both instrumental variables are relatively strong, with $\mathrm{F}$-values in the first regression of more than 10. The Sargan statistic test and the endogeneity test are not significant at the 10 percent level percent. ${ }^{3}$ However, strong instrumental variables might affect the significance of the fraction of female directors. The estimations of female directors are no longer statistically significant, although the coefficients are still positive.

${ }^{2}$ This study also uses profit margin as a dependent variable, but the estimations are not presented in this publication. The estimations can be requested from the author.

${ }^{3}$ This paper only presents the Sargan test and the endogeneity test in Table 6 to prove that the endogeneity problem is fully addressed. The Sargan test and the endogeneity test are not presented in the next regression tables. 
Model 4 is the Arellano-Bond two-step approach. The lag of one period of ROA is added in the regression as this model is a dynamic model. As a consequence, the number of observations decreases. Two important statistics for creating the model are the Arellano-Bond for $\operatorname{AR}(2)$ value and the Hansen test for over-identification restrictions. At the first attempt, the study uses one period of lag of the fraction of women directors, but the Hansen test still reports significance at the 5.7 percent level. Consequently, the Arellano-Bond model is re-specified by using a two period lag of the fraction of women directors. The endogeneity is fully addressed, with the P-value of Hansen's test at more than the 10 percent level.
The findings in Table 6 show that there is a tendency that female directors can positively influence firm performance. But, the estimations lack significance. Yet, there is the possibility that the effects may be negative in Model 4 (Table 6). Thus, this finding cannot reject the first hypothesis, in which there might be no association between female directors and firm performance. This finding can be deemed robust as endogeneity has been addressed in both analyses.

\section{The effects of female directors on firm performance with respect to firm size}

This analysis divides the observations into two sub-samples according to the size of the firms, which is the proxy of firm gov-

Table 6. The Regression Estimations: ROA and Fraction of Female Directors

\begin{tabular}{|c|c|c|c|c|}
\hline VARIABLES & $\begin{array}{c}\text { (1) } \\
\text { Ols } \\
\text { Roa }\end{array}$ & $\begin{array}{c}(2) \\
\text { iv_fe1 } \\
\text { Roa }\end{array}$ & $\begin{array}{c}\text { (3) } \\
\text { iv_fe2 } \\
\text { Roa }\end{array}$ & $\begin{array}{c}(4) \\
\text { ar_bond } \\
\text { Roa }\end{array}$ \\
\hline fract_women & $\begin{array}{c}0.064 * * \\
(2.075)\end{array}$ & $\begin{array}{c}0.385 \\
(0.583)\end{array}$ & $\begin{array}{c}0.005 \\
(0.018)\end{array}$ & $\begin{array}{c}-0.059 \\
(-0.372)\end{array}$ \\
\hline ln_bsize & $\begin{array}{c}0.014 \\
(1.044)\end{array}$ & $\begin{array}{c}-0.006 \\
(-0.302)\end{array}$ & $\begin{array}{c}0.003 \\
(0.182)\end{array}$ & $\begin{array}{c}-0.061 \\
(-0.835)\end{array}$ \\
\hline prop_ned & $\begin{array}{l}-0.048^{*} \\
(-1.939)\end{array}$ & $\begin{array}{c}-0.066^{* *} * \\
(-2.194)\end{array}$ & $\begin{array}{c}-0.073 * * \\
(-2.453)\end{array}$ & $\begin{array}{c}0.036 \\
(0.243)\end{array}$ \\
\hline ln_employf & $\begin{array}{c}0.065^{* * *} \\
(26.514)\end{array}$ & $\begin{array}{c}0.030 * * * \\
(5.614)\end{array}$ & $\begin{array}{c}0.028 * * * \\
(5.299)\end{array}$ & $\begin{array}{l}-0.044 * \\
(-1.831)\end{array}$ \\
\hline block & $\begin{array}{c}0.116 * * * \\
(5.099)\end{array}$ & $\begin{array}{c}0.011 \\
(0.336)\end{array}$ & $\begin{array}{c}0.001 \\
(0.022)\end{array}$ & $\begin{array}{c}0.211 \\
(1.633)\end{array}$ \\
\hline ln_firm_age & $\begin{array}{c}0.035 * * * \\
(11.448)\end{array}$ & $\begin{array}{c}0.014 \\
(0.740)\end{array}$ & $\begin{array}{c}-0.007 \\
(-0.570)\end{array}$ & $\begin{array}{c}0.070 \\
(1.505)\end{array}$ \\
\hline debt_ratio & $\begin{array}{c}-0.372 * * * \\
(-17.361)\end{array}$ & $\begin{array}{c}-0.443 * * * \\
(-30.800)\end{array}$ & $\begin{array}{c}-0.448 * * * \\
(-31.760)\end{array}$ & $\begin{array}{c}-0.508 * * \\
(-2.422)\end{array}$ \\
\hline Lag_roa & & & & $\begin{array}{c}0.170 * * * \\
(3.622)\end{array}$ \\
\hline Fem_exp & & $\begin{array}{c}0.013 * * \\
(2.30)\end{array}$ & $\begin{array}{c}0.016 * * * \\
(2.70)\end{array}$ & \\
\hline Icb_two & & $\begin{array}{c}0.577 * * * \\
(6.13)\end{array}$ & $\begin{array}{c}0.948 * * * \\
(15.42)\end{array}$ & \\
\hline Constant & $\begin{array}{c}-0.680 * * * \\
(-10.429)\end{array}$ & & & \\
\hline
\end{tabular}


Table 6. Continued

\begin{tabular}{lcccc}
\hline VARIABLES & $\begin{array}{c}(\mathbf{1}) \\
\text { Ols } \\
\text { Roa }\end{array}$ & $\begin{array}{c}(\mathbf{2}) \\
\text { iv_fe1 } \\
\text { Roa }\end{array}$ & $\begin{array}{c}(\mathbf{3}) \\
\text { iv_fe2 } \\
\text { Roa }\end{array}$ & $\begin{array}{c}\text { (4)_bond } \\
\text { Roa }\end{array}$ \\
\hline Year & Yes & Yes & No & Yes \\
Industry & Yes & No & No & No \\
Observations & 9,884 & 9,771 & 9,771 & 4,998 \\
R-squared & 0.276 & 0.119 & 0.118 & \\
ll & -2471 & 1484 & 1475 &. \\
Number of firm_id & & 1,669 & 1,669 & 1,254
\end{tabular}

Weak-instrument-robust inference from $1^{\text {st }}$ stage regression

Test of joint significance of endogenous regressors B1 in main equation

Ho: $\mathrm{H} 1=0$ and orthogonality

conditions are valid

\begin{tabular}{|c|c|c|c|c|}
\hline Anderson-Rubin Wald test & $\mathrm{F}(28,086)=$ & 1.25 & $\mathrm{p}-\mathrm{val}=$ & 0.2875 \\
\hline Anderson-Rubin Wald test & $\operatorname{Chi}-\operatorname{sq}(2)=$ & 2.50 & p-val= & 0.2867 \\
\hline Stock-Wright LM S statistic & Chi-sq $(2)=$ & 2.50 & $\mathrm{p}-\mathrm{val}=$ & 0.2868 \\
\hline \multicolumn{2}{|l|}{ Number of Regressors } & $K=15$ & & \\
\hline \multicolumn{2}{|l|}{ Number of Endogenous Regressors } & $\mathrm{K} 1=1$ & & \\
\hline \multicolumn{2}{|l|}{ Number of Instruments } & $\mathrm{L}=16$ & & \\
\hline \multicolumn{2}{|l|}{ Number of Excluded Instruments } & $\mathrm{L} 1=2$ & & \\
\hline \multicolumn{5}{|l|}{ Test for IV (2SLS) Estimation } \\
\hline \multicolumn{4}{|c|}{ Sargan statistics (over identification test of all instruments): } & 2.153 \\
\hline & & Chi-sq (1) & $\mathrm{P}-\mathrm{val}=$ & 0.1423 \\
\hline \multicolumn{5}{|l|}{-Endog- option: } \\
\hline \multirow{2}{*}{$\begin{array}{l}\text { Endogeneity test of endogenous } \\
\text { regressors: }\end{array}$} & - & & & 0.133 \\
\hline & & Chi-sq (1) & $\mathrm{P}-\mathrm{val}=$ & 0.7151 \\
\hline
\end{tabular}

Firm performance is regressed with the female directors' measure and control variables. Roa is the net profit divided by the total assets (ROA). Fract_women is the fraction of female directors on the board. ln_bsize is the natural logarithm of the total number of directors. Prop_ned is the fraction of non-executive directors. In_employf is the natural logarithm of the total number of employees of the firm. Block is the percentage owned by the top shareholder. Ln_firm_age is the natural logarithm of (firm age +1). Debt_ratio is the total debt divided by the total assets. Lag_roa is a one period lag of ROA. ICB_two is the fraction of female directors within the same 2-digit industry code. Fem_exp is the fraction of male directors who ever worked with female directors on other boards. Model 1 employs the OLS estimation. Model 2 and Model 3 employ 2SLS with IV (Instrumental Variables). Model 4 employs the Arellano-Bond method. Roa and debt_ratio are winsorized at 1 percent and percent. The robust t-statistics of each coefficient are shown in parentheses. 
ernance. The analysis uses firms with total employees that are lower than the $25^{\text {th }}$ quartile and higher than the $75^{\text {th }}$ quartile, for small and large firms respectively.

Table 7 presents the estimations between female directors and the ROA for small firms. Almost all of the coefficients of female directors are positive and statistically significant. The endogeneity problem in Model 2 and Model 3 can be fully addressed. Consistently, the Arellano-Bond model shows that female directors can positively and significantly affect the ROA at the 5 percent level percent. Thus, the study rejects the third hypothesis.

The next regression uses large firms only as the research observation. The effects of female directors on large firms are substantially different from their effects on small firms. Table 8 shows that most of the estimations of female directors are negative. The effects are even statistically significant at the 10 percent level, after addressing the endogeneity problem (Model 2). The Arellano-Bond model supports the negative relation of female directors and the ROA for large firms although it lacks significance. Thus, the study cannot reject the second hypothesis.

One interesting result in Table 8 is the male directors' connections with female directors has an opposite direction to that expected. The male directors' connections do not affect the percentage of female directors

Table 7. Female Directors and ROA for Small Firms

\begin{tabular}{|c|c|c|c|c|}
\hline VARIABLES & $\begin{array}{c}(1) \\
\text { ols_a } \\
\text { Roa }\end{array}$ & $\begin{array}{c}\text { (2) } \\
\text { ivfe1_a } \\
\text { Roa }\end{array}$ & $\begin{array}{c}\text { (3) } \\
\text { ivfe2_a } \\
\text { Roa }\end{array}$ & $\begin{array}{c}(4) \\
\text { ar_bond_a } \\
\text { Roa }\end{array}$ \\
\hline fract_women & $\begin{array}{c}0.216^{* *} \\
(2.086)\end{array}$ & $\begin{array}{c}5.590 \\
(1.483)\end{array}$ & $\begin{array}{c}3.056^{* *} \\
(2.438)\end{array}$ & $\begin{array}{c}0.751 * * \\
(2.136)\end{array}$ \\
\hline ln_bsize & $\begin{array}{c}0.121^{* * *} \\
(3.364)\end{array}$ & $\begin{array}{c}-0.080 \\
(-0.781)\end{array}$ & $\begin{array}{l}-0.025 \\
(-0.438)\end{array}$ & $\begin{array}{l}-0.228^{*} \\
(-1.652)\end{array}$ \\
\hline prop_ned & $\begin{array}{c}0.027 \\
(0.424)\end{array}$ & $\begin{array}{c}-0.130 \\
(-1.220)\end{array}$ & $\begin{array}{l}-0.157^{*} \\
(-1.729)\end{array}$ & $\begin{array}{c}-0.006 \\
(-0.026)\end{array}$ \\
\hline block & $\begin{array}{c}0.193^{* * * *} \\
(3.060)\end{array}$ & $\begin{array}{c}0.027 \\
(0.213)\end{array}$ & $\begin{array}{c}0.000 \\
(0.002)\end{array}$ & $\begin{array}{l}0.409^{*} \\
(1.871)\end{array}$ \\
\hline ln_firm_age & $\begin{array}{c}0.100^{* * * *} \\
(8.481)\end{array}$ & $\begin{array}{l}0.157^{*} \\
(1.771)\end{array}$ & $\begin{array}{c}0.024 \\
(0.723)\end{array}$ & $\begin{array}{c}0.181 * * \\
(2.082)\end{array}$ \\
\hline debt_ratio & $\begin{array}{c}-0.482 * * * \\
(-13.832)\end{array}$ & $\begin{array}{c}-0.451 * * * \\
(-5.442)\end{array}$ & $\begin{array}{c}-0.506 * * * \\
(-11.764)\end{array}$ & $\begin{array}{c}-0.721 * * * \\
(-3.184)\end{array}$ \\
\hline Lag_roa & & & & $\begin{array}{c}0.145^{* * *} \\
(2.911)\end{array}$ \\
\hline Fem_exp & & $\begin{array}{l}0.015 \\
(1.10)\end{array}$ & $\begin{array}{l}0.017 \\
(1.26)\end{array}$ & \\
\hline ICB_two & & $\begin{array}{c}0.397 \\
(2.02)^{* *}\end{array}$ & & \\
\hline
\end{tabular}


Table 7. Continued

\begin{tabular}{|c|c|c|c|c|}
\hline VARIABLES & $\begin{array}{c}\text { (1) } \\
\text { ols_a } \\
\text { Roa }\end{array}$ & $\begin{array}{c}(2) \\
\text { ivfe1_a } \\
\text { Roa }\end{array}$ & $\begin{array}{c}(3) \\
\text { ivfe2_a } \\
\text { Roa }\end{array}$ & $\begin{array}{c}\text { (4) } \\
\text { ar_bond_a } \\
\text { Roa }\end{array}$ \\
\hline ICB_four & & & $\begin{array}{c}0.565^{* * *} \\
(5.73)\end{array}$ & \\
\hline Constant & $\begin{array}{c}-1.071 * * * \\
(-8.525)\end{array}$ & & & \\
\hline Year & Yes & No & Yes & Yes \\
\hline Industry & Yes & No & No & $\mathrm{No}$ \\
\hline Observations & 2,423 & 2,266 & 2,266 & 1,409 \\
\hline R-squared & 0.214 & -0.318 & 0.026 & \\
\hline 11 & $-1,592$ & $-1,139$ & -796.6 & . \\
\hline Number of firm_id & & 498 & 498 & 449 \\
\hline
\end{tabular}

Firm performance is regressed with the female directors' measure and control variables. Small firms refer to firms with total assets lower than the $25^{\text {th }}$ quartile. Roa is the net profit divided by the total assets (ROA). Fract_women is the fraction of female directors on the board. ln_bsize is the natural logarithm of the total number of directors. Prop_ned is the fraction of non-executive directors. In_emplyf is the natural logarithm of the total number of employees of the firm. Block is the percentage owned by the top shareholder. Ln_firm_age is the natural logarithm of (firm age +1 ). Debt_ratio is the total debt divided by the total assets. Lag_roa is a one period lag of ROA. ICB_two is the fraction of female directors within the same 2-digit industry code. ICB_four is the fraction of female directors within the same 4-digit industry code. Fem_exp is the fraction of male directors who ever worked with female directors on other boards. Model 1 employs the OLS estimation. Model 2 and Model 3 employ 2SLS with IV (Instrumental Variables). Model 4 employs the Arellano-Bond method. Roa and debt_ratio are winsorized at 1 percent and 99 percent. The robust t-statistics of each coefficient are shown in parentheses.

on the boards. It is likely that the females' connections are not an essential feature for female director candidates to be appointed to large firms.

\section{Research Discussion}

There is a little evidence that the fraction of female directors can positively and directly influence firm performance as the relationship lacks significance. This study supports previous studies, which found difficulty in finding a direct and positive association between female directors and firm performance, such as those by Smith et al. (2006) Adams and Ferreira (2009), Jurkus et al. (2011), and Ahern and Dittmar (2012).
One of the possible reasons is due to imposing quotas, which forces the firms to appoint more female directors. The latest figures have shown that firms tend to appoint women as non-executive directors, while the number of female executive directors - who are responsible for running the firm - remains stagnant (Stern 2014). The contributions of these non-executive female directors to firm performance are less visible, as they are responsible for the monitoring roles, for example the CEOs' turnover and financial reporting standards.

Furthermore, the imposition of gender diversity is applied in the developed markets, while most of the stock market regulators in 
Table 8. Female Directors and ROA for Large Firms

\begin{tabular}{|c|c|c|c|c|}
\hline VARIABLES & $\begin{array}{c}\text { (1) } \\
\text { ols_a } \\
\text { Roa }\end{array}$ & $\begin{array}{c}(2) \\
\text { ivfe1_a } \\
\text { Roa }\end{array}$ & $\begin{array}{c}\text { (3) } \\
\text { ivfe2_a } \\
\text { Roa }\end{array}$ & $\begin{array}{c}\text { (4) } \\
\text { ar_bond_a } \\
\text { Roa }\end{array}$ \\
\hline fract_women & $\begin{array}{c}0.070^{* *} \\
(2.310)\end{array}$ & $\begin{array}{l}-0.528^{*} \\
(-1.664)\end{array}$ & $\begin{array}{c}-0.251 \\
(-1.617)\end{array}$ & $\begin{array}{l}-0.045 \\
(-0.729)\end{array}$ \\
\hline ln_bsize & $\begin{array}{c}0.193^{* * *} \\
(9.336)\end{array}$ & $\begin{array}{c}-0.004 \\
(-0.224)\end{array}$ & $\begin{array}{c}-0.001 \\
(-0.052)\end{array}$ & $\begin{array}{l}-0.050 \\
(-1.166)\end{array}$ \\
\hline prop_ned & $\begin{array}{c}0.166^{* * *} \\
(4.152)\end{array}$ & $\begin{array}{c}0.029 \\
(0.736)\end{array}$ & $\begin{array}{c}0.011 \\
(0.289)\end{array}$ & $\begin{array}{c}-0.071 \\
(-0.673)\end{array}$ \\
\hline Block & $\begin{array}{c}0.022 \\
(0.672)\end{array}$ & $\begin{array}{c}-0.089 * * \\
(-2.336)\end{array}$ & $\begin{array}{c}-0.091 * * \\
(-2.453)\end{array}$ & $\begin{array}{c}0.102 \\
(0.763)\end{array}$ \\
\hline ln_firm_age & $\begin{array}{c}0.004 \\
(1.306)\end{array}$ & $\begin{array}{c}0.004 \\
(0.219)\end{array}$ & $\begin{array}{c}-0.012 \\
(-0.842)\end{array}$ & $\begin{array}{c}0.001 \\
(0.021)\end{array}$ \\
\hline debt_ratio & $\begin{array}{c}-0.189 * * * \\
(-4.318)\end{array}$ & $\begin{array}{c}-0.291 * * * \\
(-13.650)\end{array}$ & $\begin{array}{c}-0.298 * * * \\
(-14.853)\end{array}$ & $\begin{array}{c}-0.119 \\
(-1.090)\end{array}$ \\
\hline Lag_roa & & & & $0.165^{*}$ \\
\hline Fem_exp & & $\begin{array}{c}-0.023 * * \\
(-1.98)\end{array}$ & $\begin{array}{c}-0.027 * * \\
(-2.34)\end{array}$ & \\
\hline ICB_two & & & $\begin{array}{c}1.39 * * * \\
(12.64)\end{array}$ & \\
\hline ICB_three & & $\begin{array}{c}0.737 * * * \\
(6.17)\end{array}$ & & \\
\hline Constant & $\begin{array}{c}-0.337 * * * \\
(-6.733)\end{array}$ & & & \\
\hline Year & Yes & No & Yes & Yes \\
\hline Industry & Yes & No & No & No \\
\hline Observations & 2,691 & 2,586 & 2,586 & 1,810 \\
\hline R-squared & 0.192 & 0.061 & 0.091 & \\
\hline $\mathrm{Ll}$ & 753.9 & 2,372 & 2,415 & . \\
\hline Number of firm_id & & 429 & 429 & 414 \\
\hline
\end{tabular}

Firm performance is regressed with the female directors' measure and control variables. Large firms refer to firms with total assets higher than the $75^{\text {th }}$ quartile. Roa is the net profit divided by the total assets (ROA). Fract_women is the fraction of female directors on the boards. In_bsize is the natural logarithm of the total number of directors. Prop_ned is the fraction of nonexecutive directors. In_emplyf is the natural logarithm of the total number of employees of the firm. Block is the percentage owned by the top shareholder. Ln_firm_age is the natural logarithm of (firm age +1). Debt_ratio is the total debt divided by the total assets. Lag_roa is a one period lag of ROA. ICB_two is the fraction of female directors within the same 2-digit industry code. ICB_three is the fraction of female directors within the same 3-digit industry code. Fem_exp is the fraction of male directors who ever worked with female directors on other boards. Model 1 employs the OLS estimation. Model 2 and Model 3 employ 2SLS with IV (Instrumental Variables). Model 4 employs the Arellano-Bond method. Roa and debt_ratio are winsorized at 1 percent and 99 percent. The robust t-statistics of each coefficient are shown in parentheses. 
the developing countries do not restrict it. In other words, firms in the developed countries have less flexibility to compose their optimal board structures, because their boards are assembled as a result of certain types of pressure being applied, rather than purely from their businesses' perspectives.

In the UK's case, the London Stock Exchange (LSE) is slightly more unique, in terms of its governance standards. Large listed firms experience stricter rules for their governance structures than the small listed firms do. The recommendation of gender diversity on the boards is aimed at the FTSE100 firms rather than all the LSE listed firms. The UK's small listed firms have the flexibility to appoint female directors, which can lead to better firm performance. Therefore, this study fails to show that female directors do have positive and direct impacts on firm performance.

This result also can be explained from the theoretical perspective, namely the agency theory, the resource dependence theory, the stakeholder theory, and the human capital theory. The insignificance might be a result of the incompetency of female directors, or certain external pressures to appoint female directors (i.e. female directors' quotas). In other words, the relationship between female directors and firm performance is not straightforward because there are many theories that are involved in that relationship.

Consequently, the next analysis is to split the dataset into two categories, which are small firms and large firms. This analysis is so useful because the UK's large listed firms are more regulated than the small listed ones. The findings indicate that female directors significantly affect small firms' performance after controlling the endogeneity problem, while similar findings cannot be found for the large listed firms.
The results can be explained in two ways. Firstly, the over-monitoring problem: according to Carter el al (2003), board diversity may be equivalent to board independence, and its main role is monitoring. Appointing female directors will cause overmonitoring problems for well-governed firms (Adams and Ferreira 2009; Jurkus et al. 2011). Consequently, large firms, which are the proxy of well-governed firms, do not experience positive impacts on firm performance by appointing female directors.

Secondly, the recommendations (mandatory requirements) by the UK regulator for appointing more females to the boards could be the plausible reason why the female directors' contributions in large firms is less significant than in small firms. Wintoki (2007) reports that there is no evidence the SarbanesOxley Act of 2002 (SOX) improved firm value in the US. Similarly, Ahern and Dittmar (2012) report that quotas for females did not improve firm values in Norway. The recommendation of gender diversity on boards in the UK is mainly aimed at the FTSE100 and FTSE250 firms. As a result, large firms tend to hire female directors in order to meet the regulations (quotas) rather that out of necessity or for strategic reasons. On the other hand, small firms have the flexibility to decide the make-up of their boards of directors in the absence of such regulations.

\section{Conclusion and Implications}

The mixed findings for the relationship between female directors and firm performance are the main motivation of this study. Some studies (Erhardt et al. 2003; Carter et al. 2003; Campbell and Minguez-Vera 2007, Luckerath-Rovers 2013; Liu et al. 2014; Strom et al. 2014) have found a positive association while others (Smith et al. 2006; 
Rose 2007; Adams and Ferreira 2009; Ahern and Dittmar 2012) did not find the same result. Moreover, it is reported that the relationship between female directors and firm performance is not straightforward (Adams and Ferreira 2009; Jurkus et al 2011). Given these findings, the study did not only examine the influence of female directors on firm performance, but also tried to employ a certain condition, namely firm size, in the analysis.

This study has two important findings to report. Firstly, it is less likely that female directors have a significant influence on firm performance in the UK. Even though the estimations of the effect female directors have on the ROA are positive, they are not statistically significant. Secondly, the positive impact of female directors is stronger in small firms. This may be caused because: (1) large firms, which are associated with strong governance, encounter over-monitoring problems after appointing female directors (Adams and Ferreira 2009; Jurkus et al. 2011) and (2) large firms encounter greater external intervention than small firms when it comes to the composition of their boards of directors.

This study has several implications. For firms, they should consider certain aspects when deciding to appoint female directors, in order to optimize their contribution, e.g. the firms' current levels of governance. Moreover, when firms encounter certain pressures from external parties regarding the appointment of female directors, firms must assess and select the candidates very carefully to get the most benefit from them.

For governments or market regulators, imposing quotas has successfully increased females participation on the boards, particularly in the UK. This means governments can push their agendas onto the corporate world. But, such regulations should not be too strict as the policy may not lead to a better bottom-line for the firms. Lastly, the study has confirmed that the relationship between female directors and firm performance is prone to the endogeneity problem. Further study into this topic should not rely entirely on the OLS model, as it will result in biased estimations.

\section{References}

Abbot, L. J., S. Parker, and T. J. Presley. 2012. Female board presence and the likelihood of financial restatement. Accounting Horizons 26 (4): 607-629.

Adams, R. B., and D. Ferreira. 2009. Female in the boardroom and Their impact on governance. Journal of Financial Economics 94 (2): 291-309.

Ahern, K. R., and A. K. Dittmar. 2012. The changing of the boards: The impact on firm valuation of mandated female board representation. The Quarterly Journal of Economics 127 (1): 137-197.

Bebchuk, L. A., and J. M. Fried. 2005. Pay without performance: Overview of the issues. Journal of Applied Corporate Finance 17 (4): 8-23.

Berger, A. N., and G. F. Udell. 1995. Relationship lending and lines of credit in small firm finance. The Journal of Business 68 (3): 351-381.

Brammer, S., A. Millington, and S. Pavelin. 2007. Gender and ethnic diversity among UK corporate boards. Corporate Governance: An International Review 15 (2): 393-403.

Campbell, K., and A. Minguez-Vera. 2007. Gender diversity in the boardroom and firm financial performance. Journal of Business Ethics 83 (3): 435-451. 
Carter, D. A., B. J. Simkins, and W. G. Simpson. 2003. Corporate governance, board diversity, and firm value. The Financial Review 38 (1): 33-53.

Carter, D. A., F. D'Souza, B. J. Simkins, and W. G. Simpson. 2010. The gender and ethnic diversity of US boards and board committees and firm financial performance. Corporate Governance: An International Review 18 (5): 396-414.

Chapple, L., and J. E. Humphrey. 2014. Does board gender diversity have a financial impact? Evidence using stock portfolio performance. Journal of Business Ethics 122 (4): 709-723.

Chen, Y., J. D. Eshleman, and J. S. Soileau. 2016. Board gender diversity and internal control weakness. Advances in Accounting 33: 11-19.

Dahya, J., J. J. McConnell, and N. G. Travlos. 2002. The Cadbury Committee, corporate performance, and top management turnover. The Journal of Finance 57 (1): 461-483.

Davies, E. M. 2012. Women on boards. The Davies Report.

Denis, D. J., and A. Sarin. 1999. Ownership and board structures in publicly traded corporations. Journal of Financial Economics 52: 187-223.

Erhardt, N. L., J. D. Werbel, and C. B. Shrader. 2003. Board of director diversity and firm financial performance. Corporate Governance 11 (2): 102-111.

Fama, E. F., and K. R. French. 1993. Common risk Factors in the returns on stocks and bonds. Journal of Financial Economic 33 (1): 3-56.

Farag, H., C. Mallin, and K. Ow-Yong. 2014. Governance, ownership structure, and performance of entrepreneurial IPOs in AIM companies. Corporate Governance: An International Review 22 (2): 100115.

Galbreath, J. 2011. Are there gender-related influences on corporate sustainability? A study of females on boards of directors. Journal of Management and Organization 17 (1): 17-38.

Green, C. P., and S. Homroy. 2016. Female directors, board committee, and firm performance. Working Paper. Lancaster University, Lancaster, LA1 4YX.

Gregory-Smith, I., B. G. M. Main, and C. A. O'Reilly III. 2013. Appointments, pay and performance in UK Boardrooms by gender. The Economic Journal 124 (574): F109-F128.

Haslam, S. A., M. K. Ryan, C. Kulich, G. Trojanowski, and C. Atkins. 2010. Investing with prejudice: The relationship between female's presence on company boards and objective and subjective measures of company performance. British Journal of Management 21: 484-497.

Hazarika, S., J. M. Karpoff, and R. Nahata. 2012. Internal corporate governance, CEO turnover, and earning management. Journal of Financial Economics 104: 44-69.

Hillman, A. J., A. A. Cannela Jr., and R. L. Paetzold. 2000. The resource dependence role of corporate directors: Strategic adaptation of board composition in response to environment change. Journal of Management Studies 37 (2): 235-255.

Hillman, A. J., C. Shropshire, and A. A. Cannella Jr. 2007. Organizational predictors of female on corporate boards. The Academy of Management Journal 50 (4): 941-952.

Jurkus, A. F., J. C. Park, and L. S. Woodard. 2011. Female in top management and agency cost. Journal of Business Research 64 (2): 180-186.

Kyaw, K., M. Olugbode, and B. Petracci. 2015. Does gender diverse board mean less earnings management? Finance Research Letter 14: 135-141.

Liu, Y., Z. Wei, and F. Xie. 2014. Do female directors improve firm performance in China. Journal of Corporate Finance 28: 169-184. 
Low, D. C. M., H. Roberts, and R. H. Whiting. 2015. Board gender diversity and firm performance: Empirical evidence from Hong Kong, South Korea, Malaysia, and Singapore. Pacific-Basin Finance Journal 35: 381-401.

Luckerath-Rovers, M. 2013. Female on boards and firms performance. Journal of Management and Governance 17 (2): 491-509.

Moeller, S. B., F. P. Schlingemann, R. M. Stulz. 2004. Firm size and the gains from acquisitions. Journal of Financial Economics 73 (2): 201-228.

Nekhili, M., and H. Gatfaoui. 2013. Are demographic attributes and firm characteristics drivers of gender diversity? Investigating women's positions on French Boards of Directors. Journal of Business Ethics 118 (2): 227-249.

Offenberg, David. 2009. Firm size and the effectiveness of the market for corporate control. Journal of Corporate Finance 15 (1): 66-79.

Robinson, G., and K. Dechant. 1997. Building a business case for diversity. The Academy of Management Executive 11 (3): 21-31.

Rose, C. 2007. Does female board representation influence firm ferformance? The Danish evidence. Corporate Governance 15 (2): 404-413.

Ryan, M. K., and S. A. Haslam. 2005. The glass Cliff: Evidence that women are over-represented in precarious leadership positions. British Journal of Management 16 (2): 81-90.

Sealy, R., S. Val, and S. Vinnicombe. 2007. The Female FTSE Report 2007: A Year of Encouraging Process. Cranfield University School of Management: UK.

Setia-Atmaja, Lukas Y. 2008. Does board size really matter? Evidence from Australia. Gadjah Mada International Journal of Business 10 (3): 331-252.

Simpson, W. G., D. A. Carter, and F. D'Souza. 2010. What do we know about females on boards. Journal of Applied Finance 20 (2): 27-39.

Sing, V., and S. Vinnicombe. 2004. Why so few female directors in Top UK Boardrooms? Evidence and theoretical explanations. Corpporate Governance 12 (4): 479-488.

Singh, Val, Siri Terjesen, and Susan Vinnicombe. 2008. Newly appointed directors in the boardroom: How do women and men Differ? European Management Journal 26 (1): 48-58.

Smith, N., V. Smith, and M. Verner. 2006. Do females in top management affect firm performance? A panel study of 2500 Danish Firms. International Journal Productivity and Performance Management 55 (7): 569-593.

Srinidhi, B., F. A. Gul, and J. Tsui. 2011. Female directors and earnings quality. Contemporary Accounting Research 28 (5): 1610-1644.

Stern, S. 2014. 'Men in skirts' do not enhance diversity. Financial Times: Executive Appointment 3 (April): 3.

Strom, R. O., B. D'Espallier, and R. Mersland. 2014. Female leadership, performance, and governance in microfinance institution. Journal of Banking and Finance 42: 60-75.

Terjesen, S., R. Sealy, and V. Singh. 2009. Women directors on corporate boards: A review and research agenda. Corporate Governance: An International Review 17 (3): 320-337.

Wintoki, M. B. 2007. Corporate boards and regulation: The effect of Sarbanes-Oxley Act and the exchange listing requirements on firm value. Journal of Corporate Finance 13: (2-3): 229-250.

Wooldridge, J. 2010. Econometric Analysis of Cross Section and Panel Data (2 ${ }^{\text {nd }}$ ed.). MIT: Cambridge, Massachusetts. 